\title{
Contact Biometry Measurement
}

National Cancer Institute

\section{Source}

National Cancer Institute. Contact Biometry Measurement. NCI Thesaurus. Code C87141.

Techniques to determine intraocular axial length that require contact with the eye. 